Vol. XXIV No 2018

\title{
EMPIRICAL RESEARCH ON THE STABILITY OF THE NATIONAL FINANCIAL SYSTEM
}

\author{
Leontin STANCIU, Cristian-Lucian STANCIU
}

\author{
"Nicolae Bălcescu" Land Forces Academy Sibiu, Romania
}

leontinstanciu@yahoo.com, stanciu_cristian_ro@yahoo.com

\begin{abstract}
Safeguarding the stability of the national financial system is a strategic priority of the state's economic security. In this context, based on international practices, the authors intend to identify the main features of the efforts made by the authorities of the national financial system, as well as the central bank's endeavors to ensure its stability.
\end{abstract}

Keywords: financial globalization, national financial system, financial stability, macroprudential policy, capital buffers.

\section{Introduction}

We are currently witnessing profound transformations of the national financial systems under the influence of technological innovation, liberalization and economic globalization. This economic reality has prompted specialists to affirm that "achieving financial stability is one of the new challenges that the contemporary economies have to face" [1].

In recent decades, the connection between financial globalization and the stability of the national financial systems has become increasingly evident. The national economies are increasingly interdependent as a result of the many channels of spreading the globalization. Thus, the integration of economies in the global economy is accompanied by the expansion of multinational companies, the intensification of trade and capital flows, as well as a favorable environment for the contagion phenomenon, with multiple consequences on the stability of the national financial systems [2].

In turn, financial globalization, on the one hand, has led to a continuous development of the national financial systems and, on the other hand, made them more vulnerable to contagion. Therefore, there are new risks related to capital movements and the use of the financial products (which have become increasingly complex) and their manifestation has generated financial turbulence, with considerable economic and social costs. The emergence of these risks has increased the solidarity of the international financial institutions to counteract the negative effects of the economic crises.

The process of Romania's accession to the European Union has also led to an increase in its financial vulnerability to the region's economies. This state of affairs is determined by the total liberalization of the stock account, which has generated an increase of the financial flows with the partner countries within the European Union.

2. Attributions of the Central Bank in Providing National Financial Stability The stability of the national financial system is a fundamental objective of the central 
bank. In terms of its legally invested powers, it is the core of the national financial system. Bearing the responsibility of ensuring the price stability, the central bank plays a key role in providing financial stability. At the same time, a stable financial environment creates the necessary conditions for maintaining price stability.

In exercising its functions, the central bank continuously monitors the financial developments in terms of market position and structure. At the same time, it tries to identify possible risk factors and to assess the resilience and the possible vulnerabilities of the various components of the national financial system.

In a highly versatile financial environment, achieving and maintaining financial stability involves both a continuous national and international co-operation between various regulatory and supervisory authorities, and a direct and effective dialogue between the "actors" of the national financial systems.[3]

\section{Stability of the National Financial System - Both Condition and Effect of Sustainable Economic Development}

In any efficient national economy, the stability of the financial system is a fundamental objective of all the strategic decision makers because:

- it provides the necessary environment for attracting, accumulating and efficiently using the capital;

- it guarantees funding for all the investment opportunities;

- it makes a decisive contribution to a sustainable economic growth;

- it is a fundamental condition for achieving sustainable development. The structure of a national financial system includes: the money market, the capital market, the financial infrastructure and the financial intermediaries.

In terms of defining the financial stability, there is no international consensus among the specialists on its scope of coverage. There is also no unitary approach on the role of the central banks in providing the stability of the national financial systems, even if their concern for supporting it has long become a reality [4].

We can identify a number of concepts associated with this financial concept in the literature, such as:

- the absence of generalized episodes of vulnerabilities affecting the efficient functioning of the national financial system;

- the resilience of the national financial system to endogenous and/or exogenous adverse shocks;

- the situation in which the economic performance is not potentially affected by the fluctuation of the asset prices or the inability of the institutions to meet their obligations [4];

- the state of the national financial system when it can simultaneously fulfill the following main tasks:

- the efficient, dynamic and shock-free intermediation of the financial resources;

- the prediction, the assessment and the rigorous management of the risks involved in this process;

- the absorption of the shocks which the real and financial economy undergoes and/or generates [4];

- the feature of the financial system to deal with systemic shocks on a sustainable basis and without major disturbances, to efficiently assign financial resources to the economy and to identify and manage risks effectively [5].

In view of this variety of approaches and its role in ensuring a sustainable economic development, we consider that a national financial system is stable when two fundamental conditions are simultaneously met, namely:

- it contributes efficiently to the increase of the performance of the national economy; 
- it eliminates the unbalances caused by the endogenous factors or the adverse and unforeseen events.[6]

We also argue that the involvement of the central bank, namely the National Bank of Romania, in ensuring the stability of the national financial system is an objective necessity, achievable by optimally exercising certain statutory functions, such as:
4. Risks and Vulnerabilities of the National Financial System

The financial system is a basic component of the national economic system. It has multiple connections with the real economy and the economic policies promoted by the competent authorities, as shown in the figure below.

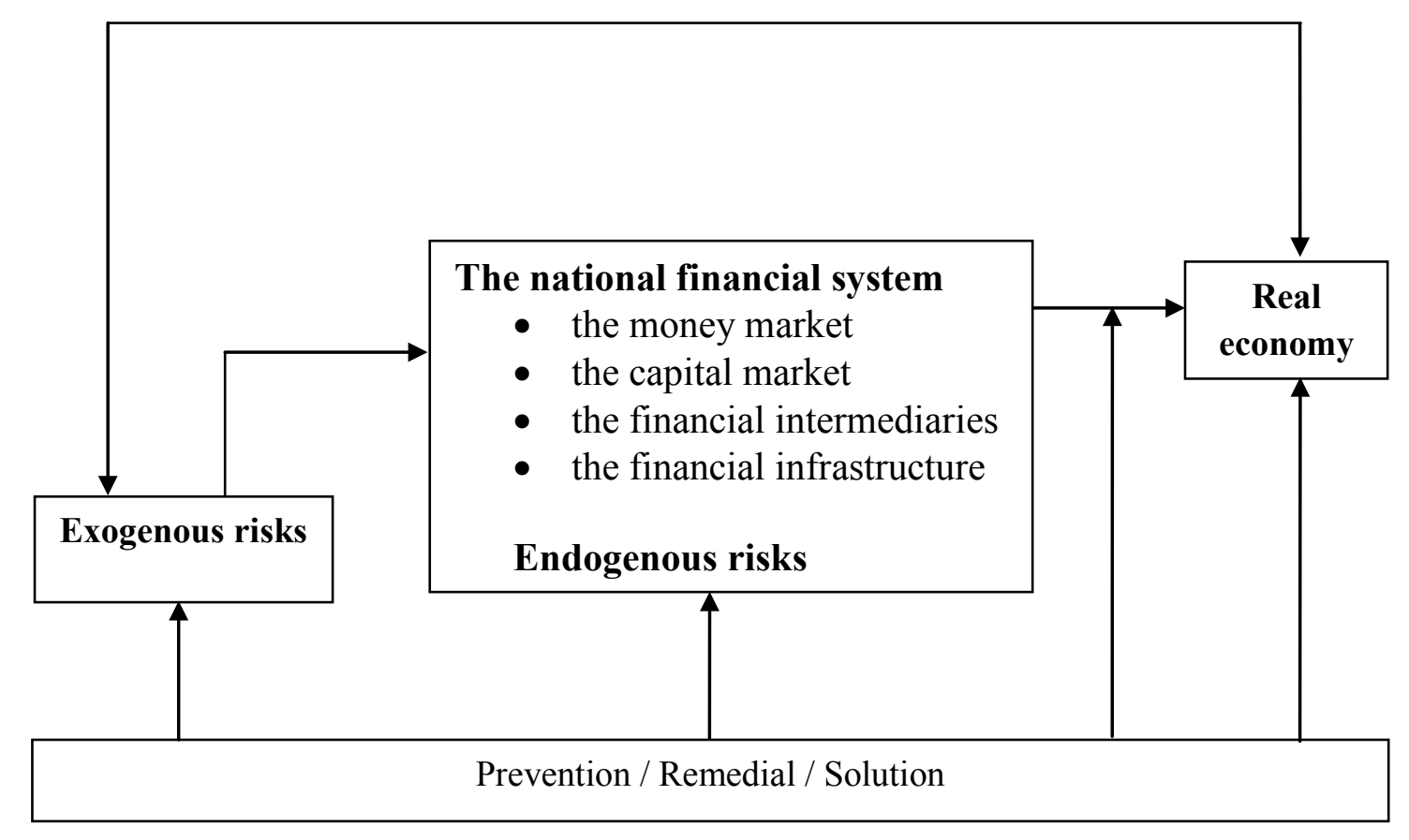

Figure 1. The structure and the connections of the stability of the national financial system (Source: Schinasi G., Defining Financial Stability, IMF Working Papers, 187, 2004, p.103)

- regulator and supervisor of the - business strategy risk; banking sector;

- manager and monitor of the payment systems;

- guarantor of the bank deposits;

- lender of last resort, and so on.

The conducted research has identified that the endogenous risks to the stability of the national financial system are the following:

- at the level of the financial intermediaries:

- financial risks (credit, liquidity, currency, interest rate);

- operational risk;

- reputational risk;
- exposure concentration risk;

- inappropriate capital risk;

- at the level of the financial markets:

- counterparty risk (commercial risk);

- asset prices volatility risk;

- liquidity risk;

- contagion risk;

- at the level of the financial infrastructure:

- risks associated with the clearing, settlement and payment system,

- loss/deterioration of confidence in the financial system; 
- fragility of the financial infrastructure (legal, audit, supervisory, regulatory);

- the domino effect.[7]

The main exogenous risks to the stability of the national financial system may be:

- macroeconomic turbulence (economic environment risk, inadequate macroeconomic policies);

- natural disasters;

- social events;

- bankruptcies of some economic branches.

\section{Capital Buffers - Macro-prudential Tools for Ensuring Financial Stability at National Level.}

In Romania, according to the recommendations of the European Systemic Risk Board (ESRB), the National Committee for Macro-prudential Oversight was established by Law no.12 / 2017 on the macro-prudential survey of the national financial system. This committee is made up of representatives of the National Bank of Romania, the Financial Supervisory Authority and the Government. RNB has a major role within this board, being responsible, among other things, for the establishment of the macro-prudential policy strategy within the limits of its competence. Up to now, RNB:

- has adopted a number of macroprudential measures on lending to the population and to the non-financial companies;

- has improved its ability to monitor and manage risks and vulnerabilities with systemic potential in the national financial system.

At EU level, the CRD IV/CRR legislative package has been adopted and applied as of 1 January 2014. It regulates the prudential activity, the supervisory framework and the prudential requirements applicable to credit institutions and the investment companies of the Member States of the European Union.
In practice, the CRD IV/CRR regulatory package provides the competent national authorities with a set of macro-prudential tools that they can use in their approach to prevent systemic cyclical risks or to mitigate the structural systemic risks, including:

1. the capital conservation buffer;

2. the countercyclical capital buffer;

3. the capital buffer for other of systemic importance institutions.

4. The capital buffer for the systemic risk [8].

The capital conservation buffer is intended to increase the resilience of the credit institutions and their ability to absorb possible banking losses. It consists of level 1 basic own fund. The implementation of this buffer is done either at an accelerated rate (according to a schedule established by the competent national authorities) or in equal installments of 0.625 percent per year (from 1 January 2016 to 1 January 2019), according to the national circumstances. At national level, as of 1 January 2016, the capital buffer is implemented in percentage steps of $0.625 \%$ per year as follows:

- from 1 January 2016 - 0.625\%;

- from 1 January 2017 - 1.25\%;

- from 1 January $2018-1.875 \%$;

- from 1 January 2019 - 2.5\%;

The Countercyclical Capital Buffer (CCB) aims to improve the resilience of the banking sector to possible shocks. The activation of this instrument is based on the information provided by the credit deviation indicator in GDP (broadly) from its long-term trend (indicator according to the ESRB). In Romania, as of 1 January 2016, the countercyclical capital buffer is maintained at $0 \%$.

The capital buffer for other systemic importance institutions (O-SII) in Romania is at a level of $1 \%$ of the total risk exposure value for all credit institutions identified as systemic.

The capital buffer for the systemic risk is used to prevent and mitigate the macro- 
prudential risk that could have consequences for the financial system and for the national economy. It consists of level 1 basic own funds of at least $1 \%$ of the exposures related to it. It may be required in graduated or accelerated installments of 0.5 percentage points, amounting to a sum between $0 \%$ and $5 \%$ of the total exposure (or more than $5 \%$ in justified cases).

\section{Conclusions}

In the context of the financial globalization, the stability of financial systems has become a topic highly approached by specialists and researchers. An efficient national financial system directly and decisively influences both the optimal allocation of resources and the performance of the economy as a whole. Also, a stable national financial system is both a condition and an effect of a sustainable economic development and of a high standard of living of the population. Therefore, the ongoing efforts and the measures taken by the prudential supervision and regulation authorities are well-justified. As a consequence, diversifying the use of modern tools in order to ensure the stability of the national financial system is a requirement for any national economy.

\section{References}

[1] Cerna, S.(coordinator), "Stabilitatea financiară", Timiş̧oara, Western University Publishing House, 2008, p.7

[2] Albulescu, C.T, "Stabilitatea sectorului financiar în condiţiile aderării României la U.E.M ", Timişoara, Wester University Publishing House, 2010, p.27

[3] Stanciu L.,Popa I.G., Cercetari empirice privind stabilitatea financiara in conditiile economiilor contemporane. Cazul Romaniei, Knowledge Based Organization International Conference,,2016.

[4] Stanciu L.,Stanciu L.M., Cercetari teoretice si empirice privind analiza si evaluarea stabilitatii sistemelor financiare nationale. Experienta Romaniei, KBO- Knowledge Based Organization International Conference, 2017.

[5] BNR, "Raport asupra stabilitătii financiare", 2006, p.7

[6] Stanciu L, Stanciu L.M, op. cit

[7] Ibidem 